\title{
Finding the hidden messages in the film "Korean War"
}

\author{
Ji-Young Yoo \\ Department of Mass Communication \\ Pukyong National University, Busan, 608-737, South Korea
}

\begin{abstract}
This research is a study of the documentary film entitled "Korean War." My research focuses on the collective trauma and amnesia of the Korean War among the people of the U.S. in an effort to understand ongoing tensions between the U.S. and the two Koreas, both North and South. A study of the film also gives a way to read the hidden meaning of the film through deconstructing the film with Peircian semiotics, and scrutinizing its artistic choices of visual language. This study provides a review of the theory of trauma. It also gives insight into understanding the perceptions of the Korean War in the U.S.
\end{abstract}

Keywords: Korean War, Peircian Semiotics, Collective Amnesia, and Trauma

\section{INTRODUCTION}

Most of Americans have no memory of Korean War. The Korean War is "The Forgotten War" for most of Americans. The well-known nickname indicates a loss of memory about the War among the people of the U.S. It denotes that they have become insensitive to their own catastrophic experiences; even though more than 37,000 U.S. soldiers were killed during the War.

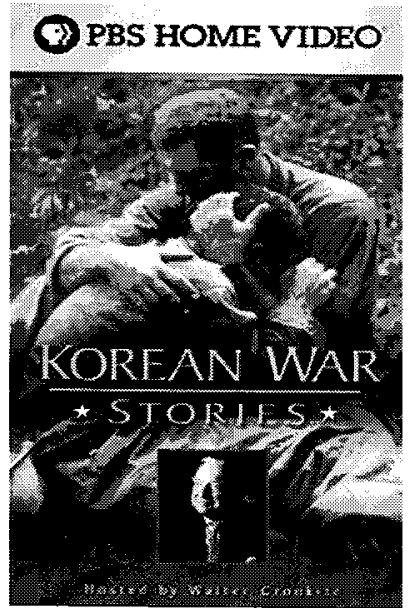

Fig. 1. The Cover of the film "Korean War"

(C) 2001 packaging PBS. All rights reserved [7]

Why have Americans forgotten their traumatic experience? The tension between the U.S. and North Korea is increasing for the nuclear weapon. In this political climate, it might be very important to understand what their experience was during the

* Corresponding author. E-mail : cydyoo@nate.com

Manuscript received Aug. 14, 2009 ; accepted Sep. 10, 2009
Korean War and how they have forgotten the War in order to find a way of reconciliation between the two countries.

The documentary film, "Korean War," was produced by New Voyage Communications, and distributed by Public Broadcasting Services in 2001 was particularly chosen with the intention to pick a film that had the least propagandist characters [7]. The film was produced to celebrate the 50th anniversary of Korean War. It reviewed the war from the perspective of Korean War veterans in the U.S. There have been many programs about the Korean War, but, it was hard to find a story from the Korean War veterans. This film also intends to raise a consciousness of The Korean War and appreciate the veterans more for their sacrifices. However, the purpose of this study is not limited to confirm whether or not the filmmaker's goal was met or achieved efficiently in the film. Rather, it attempts to find the reason for the perception of the Korean War as "the Forgotten War." This study will check whether this film just reproduce the collective amnesia. For the reason, it will, first of all, find elements that trigger the collective amnesia. If there are the elements, this study might possible to explain of the collective amnesia of the Korean War even though the veterans are exclaiming for appreciation. For the purpose, I will compare what the veterans insist in the film and what the audiences get from the film.

As the first step in examining this film, this study will analyze the film's narrative applying Peircian semiotics for an accurate understanding of the film because Peircian semiotics' triadic relations of phenomenology and signs give a great help to articulate the meaning of the contents. It will concentrate on the content, both verbal and visual images, to identify triadic relations of three phenomenological areas, such as the firstness, the secondness, and the thirdness of the documentary. Borrowing from Sheriff, finding the firstness of the film is to find out the quality, possibility or feeling of the film. The secondness is fact, reaction, and effort of the film. The 
thirdness is law, symbol, or habit of the film [6]. Through finding these triadic relations of phenomenology and signs, this study will reveal the central argument of the film.

Through deconstructing the film's contents, this study also endeavors to find the meanings of this film that are not only on surface, but also the meanings built underneath the content.

The content analysis is incorporated with the theory of trauma to support the main method of Peircian semiotics analysis.

As background, I present with the following chart of the 10 semiotic signs drawing upon Peircian semiotics [6].

Table 1.: Semiotic10signs [6].

\begin{tabular}{|c|c|c|c|}
\hline \multirow[t]{3}{*}{$\begin{array}{l}\text { Iconic } \\
\text { signs }\end{array}$} & $\# 1$ & $\begin{array}{l}\text { Rhematic } \\
\text { iconic } \\
\text { qualisigns }\end{array}$ & $\begin{array}{l}\text { Feeling, } \\
\text { emotion, } \\
\text { overall quality }\end{array}$ \\
\hline & $\# 2$ & $\begin{array}{l}\text { Rhematic } \\
\text { iconic } \\
\text { sinsigns }\end{array}$ & Physicality \\
\hline & $\# 5$ & $\begin{array}{l}\text { Rhematic } \\
\text { iconic } \\
\text { legisigns }\end{array}$ & Iconic \\
\hline \multirow[t]{4}{*}{$\begin{array}{l}\text { Indexical } \\
\text { sign }\end{array}$} & $\# 3$ & $\begin{array}{l}\text { Rhematic } \\
\text { indexical } \\
\text { sinsigns }\end{array}$ & $\begin{array}{l}\text { Unexpected, } \\
\text { spontaneous, indicates } \\
\text { an object without } \\
\text { conveying much about } \\
\text { its sense or depth }\end{array}$ \\
\hline & $\# 4$ & $\begin{array}{l}\text { Dicentic } \\
\text { indexical } \\
\text { sinsigns }\end{array}$ & $\begin{array}{l}\text { Provides information } \\
\text { about its object by } \\
\text { being actually affected } \\
\text { by that object }\end{array}$ \\
\hline & \#6 & $\begin{array}{l}\text { Rhematic } \\
\text { indexical } \\
\text { legisigns }\end{array}$ & $\begin{array}{l}\text { Indicating, pointing to } \\
\text { the object, This or } \\
\text { That }\end{array}$ \\
\hline & $\# 7$ & $\begin{array}{l}\text { Dicentic } \\
\text { indexical } \\
\text { legisigns }\end{array}$ & $\begin{array}{l}\text { Conventional sign, } \\
\text { simultaneously tells us } \\
\text { some information } \\
\text { about its object }\end{array}$ \\
\hline \multirow[t]{3}{*}{$\begin{array}{l}\text { Symbolic } \\
\text { sign }\end{array}$} & $\# 8$ & $\begin{array}{l}\text { Rhematic } \\
\text { symbolic } \\
\text { legisigns }\end{array}$ & Art, aesthetics \\
\hline & $\# 9$ & $\begin{array}{l}\text { Dicentic } \\
\text { symbolic } \\
\text { legisigns }\end{array}$ & Criticism \\
\hline & $\# 10$ & $\begin{array}{l}\text { Argumentive } \\
\text { symbolic } \\
\text { legisigns }\end{array}$ & Theory, argument \\
\hline
\end{tabular}

\section{MAIN ANALYSIS}

\subsection{Hidden elements-studying with intuition}

This study found, through the Peircian Semiotic analysis, that this movie tries to change the public view of the Korean War, as the forgotten War by telling the personal stories of the veterans. It insists that Korean War shouldn't be forgotten because the veterans sacrificed much to rescue many Koreans from the Communist oppression. This argument also was evident in the film's press release [7] in which the filmmaker stated that the film's intention was to raise the public's consciousness of the Korean War. According to the Peircian semiotic analysis, the film well exploited materials, feelings or emotions, and visual composition in the film, with precise calculations to achieve the filmmaker's goals (sign \#2,1, \& 5). Sign \#2 is represent physicality; therefore, the film's materials become the sign \#2. The film's feeling or emotion becomes the sign \#1. And the composition of the film is iconic sign \#5. By using various film elements in a calculated way, the film succeeded in conveying the message that the Korean War shouldn't be forgotten because of the veterans' sacrifices to its audience. This message is an external message. If this message is successful transmitted to the audiences, the Forgotten War will be revaluated.

However, this study found that sometimes the film creates a very emotional mood. The emotion is heightened by feelings identified as patriotism and as national pride in the U.S. Feeling of national pride and patriotism were created through an interaction of different semiotic signs within the film. Strong feelings of national pride and patriotism were created in the background mood, while the main argument was being developed. Yet, the mood of national pride and patriotism was very strong. Because the nation pride and patriotism is too strong, its' external message is effaced by them according to my intuition. I intuitively concluded that these feelings were the hidden elements I sought. They erase the pain of the Korean War and provoke the collective amnesia of the war. Deleuze said, "intuition is the method of Bergsonism. Intuition is neither a feeling, an inspiration, nor a disorderly sympathy, but a fully developed method, one of the most fully developed methods on philosophy" [2]. Deleuze said that Bergson used intuition as a fully developed method. Encouraged by Bergson, I decided to follow my intuition about the feelings. According to my intuition, the nationalism and patriotism for the U.S. are the hidden elements that have provoked the collective amnesia of the Korean War and have erased the pain. as a first step, the second analysis will focus on finding national pride and patriotism within the film. To prove my intuitive assumption, this study will search for the mechanism that erases agony by the patriotism and national pride and pursue a content analysis of the film in the following chapter.

\subsection{National Pride and Patriotism in the Film}

This film opens with the Korean War memorial (sign \#8) in Washington D.C. The statues of the soldier are grand and impressive enough to draw much attention from the audience. In the dawn's early light, these veteran figures look heroic, even sublime. These majestic images of the veterans reflect respect for the veterans' patriotism. Right after the images of the sculptures, the number of casualties from the Korean War is announced by the well-known journalist Walter Cronkite (sign \#6). The numbers indicate soldiers' sacrifices for the U.S. This casualty number is embodied by footage of wounded soldiers (sign \#2). The wounded soldiers are the physicality of the number. They give the audiences vivid images of the veterans' sacrifices. Some footage in the film shows a contrast (sign \#2) in the physical traits of Americans and South Koreans. The clean, tall, strong images of Americans are 
compared with the dirty, dark, short images of South Koreans.

By their physical traits(sign \#2), Americans gain very positive feelings(sign \#1); they are confident, determined, and powerful. With their superior mental and physical strength, the U.S. soldiers operated a sublime mission during the Korean War. The veterans were on a mission to protect the freedom of South Koreans from the Communist aggression. This comparison promotes a feeling of national pride for the U.S.'s humanistic efforts.

The images of Korean children often are used as examples to show the U.S. soldiers' compassion for Koreans (sign \#2). One veteran testified that he found a small Korean child, crying right next to his/her old man's dead body. During the interview, he showed his genuine compassion for the child. His compassion seemed to represent the compassionate feelings of all Americans toward Koreans. By showing the soldier's compassion in the film, the U.S. military action in Korea could be justified as an action to protect poor Koreans. The stories of Korean children repeatedly were presented throughout the whole film. These stories generate national pride as rescuers and protectors for the people in the U.S. When the narrator states, "Americans had to fight for another country's freedom," it is presented with a strong, determined voice. By hearing the statement, the American audiences might feel national pride.

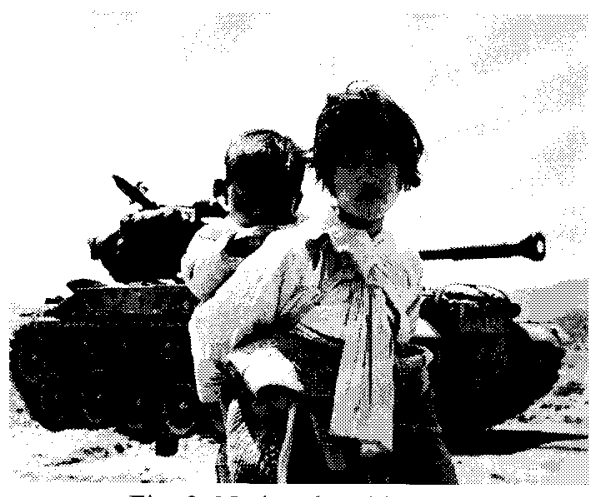

Fig. 2. National archives.

The U.S. becomes a savior of South Koreans from communist brutality when a South Korean reporter insists that Koreans owed the U.S. for their freedom (sign \#2). His comment justifies the U.S. involvement in the war, even though the Korean War was a conflict between the same people of one nation.

The scenes of military recruitment, when the veterans explain why they joined the military, are the most direct indication of the film's strong patriotic sentiment. Many say they joined the military because of their patriotism for the U.S. The newly recruited young men are shown, being sworn into service by raising their right hands. The conventional sign of swearing ( $\operatorname{sign} \# 7$ ) implies their patriotism for the U.S. The veterans said that they automatically assumed that their country was completely right. Their national pride was too strong to doubt their country's decision. The veterans' decision to participate in the war was made by the simple naïve thought, that their country was unconditionally right; without any thoughtful examination of the war, they enlisted. The veterans' unprocessed thoughts suggested that their patriotism was reckless. Throughout the whole film, there is never any sign of a serious criticism against the veterans' reckless patriotism, in spite of their tremendous sacrifices.

The technical superiority of the U.S. military was another important component that triggered the American audiences' national pride and patriotism. Interviews with U.S. pilots said that U.S. air power was invincible to that of any other country. One pilot said that North Korean or Chinese pilots couldn't even compete with the U.S. pilots because of their poor air fighting techniques. Only the Soviet Union pilots were supposed to be sophisticated enough to challenge the U.S. air force. With its discussion of the superior technology and incomparable air fighting techniques of the U.S. soldiers, the national pride being generated in the film reached its zenith during this sequence.

Consequently, the film promotes national pride and patriotism toward the U.S. by depicting Americans as being compassionate, powerful, and technically superior. The emphasis on national pride and patriotism was strongly connoted underneath the film's direct message.

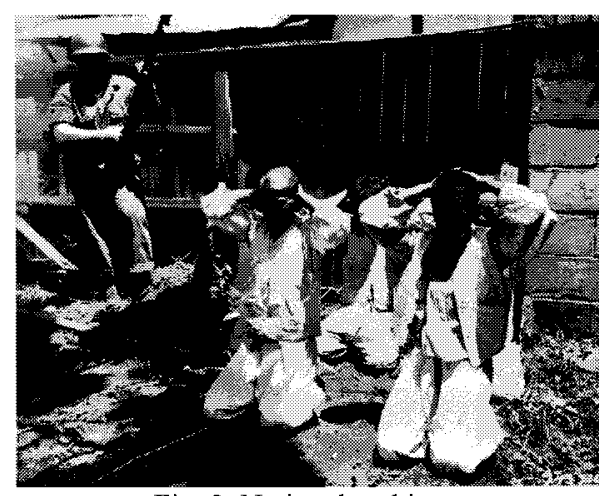

Fig. 3. National archives.

\subsection{The Veterans' Traumatic Experiences}

While watching the film, the audiences can find how much the veterans suffered during the Korean War. The film, "Korean War," provides many painful stories of the veterans. Some veterans had bedewed eyes while giving the interviews. Some veterans described how they had lost their fellow soldiers. One veteran mumbling and teary-eyed, couldn't even finish his sentence because of his sorrow. A veteran described how landmines blew up his legs and arms. Another veteran described the moment that he had to leave behind his fellow soldiers in order to survive himself. These experiences of the veterans were very painful and sad for anybody to hear.

Their agonizing stories share a character of "trauma," as defined by Cathy Caruth in her book, Unclaimed Experience:

In the most general definition, trauma describes an overwhelming experience of sudden or catastrophic events in which the response to the event occurs in the often delayed, uncontrolled repetitive appearance of hallucinations and other intrusive phenomena [1].

The veterans' experiences might be categorized as traumatic because of their overwhelmingly catastrophic nature. According to Caruth's definition, the veterans' sorrowful 
experiences won't be easily forgotten. She said that traumatic experiences occur unexpectedly and repetitively as hallucinations. Therefore, the veterans' trauma of the Korean War cannot be forgotten to the veterans who directly experienced it. Rather, the trauma will randomly resurface, and remind them of their pain.

One veteran who told his story even named his condition during the battle as "trauma." He said that a large number of Chinese volunteers were participating in the Korean War. Unfortunately, they were not as well-equipped as the U.S. soldiers. Some didn't even have guns, so they had to scavenge their fellow soldiers' guns after the soldiers died. Even if this veteran and his fellow U.S. soldiers knew that the Chinese were not well prepared, they still had to shoot the Chinese to save themselves. Consequently, many Chinese volunteers were killed without offering any strong resistance. The Chinese corpses piled up high in front of the U.S. soldiers. The veteran and his fellow soldiers were shocked and stopped shouting because they felt panicked about killing so many Chinese volunteers. They thought that killing human beings was a serious, catastrophic experience, even though it was necessary for their own survival. Due to this reason, the veteran identified his feelings as traumatic.

Another veteran described his post-war symptoms, saying that he dreamed every night about the Korean War. In his dream, he never returns home from Korea. This reoccurring dream indicates the veteran's fear of his dreadful experience during the Korean War. His experience also can be categorized as traumatic because of the hallucinatory and repetitive nature of the psychic intrusions. He said that his experience has not been erased by time. His experience was inscribed in his mind, and it hasn't grown lighter or healed even though over fifty years has passed. Many veterans said in the film that it was impossible to forget the war.

Cronkite, the narrator, states at the beginning of the film that the Korean War is "the forgotten War" for the general public; yet it can not be a forgotten war for the Korean War veterans who risked their lives and suffered so much. The veterans' agonizing experiences may last for their entire lives. Therefore, if the audience experiences the veterans' sorrowful feelings, they will not forget the Korean War, just like the veterans. This film initially tried to make the audiences experience the veterans' pain by sharing their stories.

\subsection{The role of National Pride and Patriotism}

Unfortunately, the veterans' trauma did not get successfully transmitted to the audiences, even though the stories were painful enough to be inscribed on the audiences' mind. The reason for this disconnect is because the agonizing emotions dissolve before the audiences fully feel them. The dissolve brings in other film elements specifically feelings of U.S. national pride and patriotism. These feelings were presented cleverly in the film, and interrupted the audiences from experiencing the veterans' sadness. The interruption prevented the audiences from feeling empathy toward the Korean War veterans. Therefore, the stories of the Korean War haven't remained for a long time with the audience because they didn't feel the veterans' trauma. For an audience who doesn't have any direct experience of the Korean War, it might be very hard for them to remember the War. If the pain of the veterans were transmitted successfully to the audiences, the audience could experience its own trauma by watching the film and remembering the Korean War; however, the film didn't deliver that impression to its audience because the pain was effaced by the film's national pride and patriotism.

Several instances illustrate how national pride and patriotism eradicate the plaintive emotions in the film. Foremost, the film proved that the composition of the film was the most effective way of erasing the pain of the War. In the first analysis of the film, I identified an unexpected composition of images that interrupted the main argument that the war was "the war should be remembered." The two important elements, the veterans' individual stories and the historical explanation of the War intriguingly were composed together (sign \#5).

The individual stories represent the veterans' pain over their war experiences. For example, they say they saw their comrades being killed. They also witnessed the suffering of many Korean civilians, especially young children grieving a family member's death. Some even talk about their own near death experiences. These experiences and painful feelings created by the stories composed the firstness of the film. These personal stories were shown together with the footages of the dead and wounded soldiers which are physicality. (sign \#2). These dreadful images escalated the emotion to extremely high; the audiences could feel the same emotion while watching the footage. However, the film doesn't allow the audiences to have enough time to develop empathy. Thus, the audience is unable to elevate its initial compassion toward the veterans. The film rather abruptly switches from personal stories to the greater war narrative from the U.S. national perspective. This interruption, the secondness, continuously occurs from the beginning to the end of the film. By switching the stories, the film interrupts the audience from developing its own reaction. Therefore, the audience also loses its opportunity for the thirdness, rationalization of the film's firstness and secondness. Therefore the audiences don't have a chance to be critical about the reasons why the U.S. first entered the War. The meta-narrative that is offered in the film explains why and how the Korean War started and developed instead. Some veterans talk about the problems that arose when the Chinese volunteers got involved. They said that they were overwhelmed by the large number of Chinese soldiers, and that they felt panic. Conversely, the film starts by giving the number of the U.S. casualties and summarizes their loss in a sudden manner. Thus, instead of thinking about why and how the veterans felt panicked by the Chinese, the film jumps to the historical record of the casualties. This sudden interval of the historical record impersonalizes the veterans' experiences to the historical context. This impersonalization of the veterans' stories by presenting a chronology of the war was used repeatedly throughout the film. By giving historical references, the individual stories lose their specificity. Further, individual responses and feelings were not transmitted to the audiences through this impersonalization of individual stories. 


\subsection{Impersonalizing the personal stories}

In the film called "Hiroshima Mon Amour," [5] the protagonist, a French woman, scratches her own hand on a wall, inflicting physical pain to express her mental pain over losing her lover. She was treated as insane because of her selftormenting behavior. As the wound gradually recovers, she also forgets the pain of losing her lover. By seeing the reality around her and the larger history, she could forget of her own mental pain. As Caruth observed of the film heroine: "It is likewise the unavoidable reintegration of the body in the recovery of her hands that represents a betrayal in the forgetting imposed by the sight and understanding of a larger history" [1]. The French woman could forget her boyfriend's death by forgetting the specificity of his death, and by realizing her own life. She said, "I see my life. Your death" [1]

Caruth defined the meaning of "see":

[T]his forgetting is enacted in her use of voir, "to see," which begins as a literal perception, ..... subsumes the event of death in the continuous history of her life. Seeing thus inaugurates the forgetting of the singularity of her lover by forgetting the referential specificity of his death [1].

Caruth interpreted the French woman's comment as meaning that the French understood the tragedy of Hiroshima as "the end of their own suffering" [1]. The French didn't look at it as the beginning of the suffering for the Japanese. The French perceived the nuclear bombing in Hiroshima as "the end" of the World War II; this perception effaces the Japanese past event, and thus inscribes it into the meta-narrative of France as a reference [1]. Thus, the French relate Hiroshima with only the end of the World War II and the France's liberation from Germany. However, they don't remember the tragic deaths in Hiroshima or Nagasaki. With similar thetoric, the film "Korean War" turns the tragedy of the Korean War as into a sublime act, by presenting the event in the larger context of U.S. history. As the French history erases the deaths of Hiroshima to celebrate their own liberation, the effacing of the deaths of U.S. soldiers and Korean civilians becomes necessary to celebrate the great history of the U.S. as a rescuer of Koreans. To repeat, the Korean War veteran's trauma becomes interpreted through U.S. history and the Korean War, which retrospectively is interpreted as a victory.

Consequently, this historical interpretation makes the people in the U.S. to interpret the Korean War as a humanistic rescue and a sublime act, instead of event causing the death and suffering of hundreds of thousands of war participants.

Caruth looks at this denial of the death as a kind of moral betrayal.

He: What's the film you're playing in?

She: A film about Peace. What else do you expect them to make in Hiroshima except a picture about Peace? [1]

Caruth thinks that the French woman's response reflects how the French perceive other people's catastrophic events. Caruth considers it a betrayal for the Japanese to make a story about peace in a place where so many Japanese suffered and were killed. The perception of Hiroshima as a place of peace can only be from the French perspective. The French associate peace with Hiroshima because they were liberated on the day Hiroshima was bombed. But, for the Japanese, Hiroshima is a place of death. Caruth said, "It is indeed the necessary betrayal of the particular past in the understanding of a history that constitutes the story the French woman comes to tell the man" [1]. In her comment, Caruth said that, since the French woman wanted to talk about her own story, she looks at Hiroshima from her own perspective, without considering the Japaneses' point of view. Similarly, in the film "Korean War", since the U.S. wanted to present the Korean War as the proud history of a victory, the veterans' painful experiences were interrupted by the meta-narrative. The most interesting aspect of national pride and patriotism in the film occurs during an interview with a veteran who still had tremendous pain from his war injury. His testimony in particular gives a clear idea of the veterans' patriotic emotions for the U.S. He says that he despaired because his two legs were amputated. When a doctor told him that there was a good news for him, he was just sarcastic because of his desperate situation. He said, "What can be the good news when both your legs are amputated?" However, he expressed a joyful mood when he heard that division in which he fought had won a major battle. The story of the triumph he heard from the doctor helped to build a collective identity centered on his fellow soldiers.

Bernhard Giesen explained:

Collective identity is constructed according to a similar logic. Like birth and death, which set the frame for the continuity and unity of the individual existence, referring to a past as a collective triumph or a collective trauma transcends the contingent relationships between individual persons and forges them into a collective identity [3].

Giesen said that the triumph transformed the relationship from one based among individual soldiers to one based on a collective identity. While the previously mentioned veteran was in the tremendous physical pain, he was very sad and depressed by his pain and disability. The triumph he felt after talking with the doctor, however, sent his mood into a completely different direction. He identified himself with his fellow soldiers because they shared a collective triumph; therefore, he didn't feel sad anymore, and shared the victory with other fellow soldiers. In his case, his identity was reconstructed by the triumph he experienced when informed about his unit's good news. The victory transforms his pain into happiness, pride, and patriotism for the U.S. In this case, the triumph was the element that reconstructed a collective identity for the wounded soldier. Similarly, if the audience shares traumatic or triumphant experiences with the veterans on screen, they remember the Korean War like the veterans; the audience members identify themselves with the veterans who were traumatized by the Korean War. Thus, this film wanted to share the veterans' experiences to create a collective identity among the audience. By sharing their experiences, the filmmakers hoped to persuade people to remember the War. In this example, the veteran was rather happy despite his severe 
injury. His mood switched from sadness to the pride and patriotism toward the U.S. by identifying himself with other veterans who had a victory in a battle. Therefore, the audience, who earlier felt compassion for this wound; then feels his greater sense of pride and patriotism in the U.S. This shift is another example of how the traumatic pain from the war is diluted by the feelings of national pride and patriotism.

Incorporating Caruth's idea of trauma and Giesen's idea of collective identity, this study concluded that the film particularly emphasized the story of this veteran was seriously injured in order to make audiences feel national pride and patriotism through their identification with him. So far this study has proved that the national pride and patriotism systematically effaces the traumatic pain of war veterans. By effacing the pain, the audience neither feels empathy nor identifies with the veterans. As a result, the film's main argument (sign $\# 10$ ), i.e. "the Korean War shouldn't be forgotten because of the veterans' sacrifices," did not strongly make sense to the audiences. Instead, a hidden, non-verbal statement (sign \#10) of this film challenged the film's main argument that the war was forgotten. The hidden message suggested to the audience that the Korean War should not be remember as the traumatic war, but rather, as a part of sublime U.S. history. In other words, the direct verbal message of the film that the Korean War should be remembered and admired was denied by the film's hidden element, i.e. the patriotic sentiments.

\subsection{Collective Amnesia}

By observing the systematic ways in which the soldiers' traumatic pains were effaced by feelings of national pride and patriotism in the film, I concluded that the collective amnesia of the Korean War in the U.S. might have happened through a process similar to the rhetoric deployed in the film. The Korean War was a traumatic experience, not only for the veterans, but also for the U.S. as a nation. Retrospectively, the most powerful country in the world couldn't achieve complete domination over a newly started communist country. It was interrupted in the middle of the war without any clear resolution. This catastrophic experience became a collective trauma of the U.S. Its national pride was shattered. Therefore, the U.S. needed to build up its pride and to strengthen its national identity.

As Arthur Neal argued:

All collective traumas have some bearing on national identity. While in some cases national trauma results in enhancing a sense of unity within a society, there are other cases in which collective traumas have fragmenting effects.... Through the epic struggles of the American Revolution and the American Civil War we came to recognize more clearly what it means to be an American... [4].

Arthur claimed that collective traumas strengthened unity among Americans during the American Revolution and the American Civil War. Yet, in order to build strong unity, the collective traumas they experienced must be reinterpreted. Giesen insists that traumas have to be restated and mystified, and also that the traumatic past shouldn't be presented with specificity [3]. Because they refer retrospectively to liminal horizons of the social community, triumph and trauma have to be imagined, renarrated, and visualized in myths, pictures, and figures. Thus, the triumphant and sovereign subjectivity is embodied in the figure of the hero, who lives beyond the rules and establishes a new order. In contrast, the traumatic reference to the past is represented by the memory of victims who have been treated as objects as cases of a category without a face, a name, a place [3].

According to this study, the film "Korean War" can be viewed, bearing in mind Giesen's observation about the need to develop nationalistic unity after a collective trauma. The film simultaneously presents traumatic experiences of the veterans, along a strong patriotic mood. Through this manner, the traumatic experience becomes a chance to build the national pride and patriotism. To build a new history, the veterans' traumas lose their specificity by being juxtaposed with the historical record of the war. This pattern is not shown, just in the film, but also manifests itself as social phenomena.

As a recent example, in the Gulf War, we hear more about where and how the U.S. occupied the area, rather than on how many soldiers were killed. The official record downplays the number of casualties, so the specificity of the casualties becomes unconceivable. The traumatic war experiences are used to promote patriotic sentiments among the people in the U.S. This pattern tries to build a strong, collective unity among the people of the U.S. against the enemies, and also tries to generate national pride. Applying the same logic, the Korean War, as a collective trauma of the U.S., is forgotten consciously, and the national pride and patriotism is promoted instead.

\section{CONCLUSION}

As I mentioned in the beginning of this study, the Korean War has been forgotten for the most of Americans. Many Americans have criticized Vietnam War. On the contrary, many Americans don't even remember the Korean War. The Korean War also is known as the "Forgotten War". Korean War, the first encounter with the communist, was a trauma for Americans because of tremendous loss of lives.

The reason of this study was to understand the U.S. perspective of the Korean issue, and thus, to develop a deeper understanding of the issues on the Korean peninsula. Recently the tension between the U.S. and North Korea is increasing for the nuclear weapon. In this political climate, it might be very important to understand Americans' understanding of their history with both South and Nouth Korea in order to find a way of reconciliation between the U.S. and the two Koreas. Therefore, I decided to study the film, "Korean War" that was released for the fiftieth anniversary of the Korean War because it was shown in the public channel that has less commercial influence. The filmmaker insisted that its purpose was to give a chance for Korean War veterans to talk about their perspective of the War and to remind the people in the U.S. to appreciate their sacrifices. After I analyzed this film with Peircian semiotics and with trauma theory, I have concluded that national pride and patriotism 
were the reasons of the collective amnesia. By these national pride and patriotism, individual's voices become impersonalized. It discourages people feeling the empathy on the veterans. Even though the veterans wanted to remind people in the U.S. about their sacrifices, the U.S. resituated their history with the proud U.S. history of its humanistic efforts to protect Koreans from communist occupation. With these reasons I mentioned, the Korean War becomes "the Forgotten War". I want to conclude this study with Caruth's explanation of the trauma.

Caruth explained history as a resituated story for trauma;

Through the notion of trauma, I will argue, we can understand that a rethinking of reference is aimed not at eliminating history but at resituating it in our understanding, that is, at precisely permitting history to arise where immediate understanding may not [1].

According to Caruth, the traumatic experience of the Korean War was resituated as a history. The U.S. changed the story from the unresolved War to a victory against communism.

This study concludes that many Americans are misunderstanding their history with two Koreas as an triumphant event. This lack of undertanding might help to make a wrong political decision on the issues with Koreas. For the future study, I would like to research more about other reasons of this collective amnesia and misunderstanding of the Korean War, and how they affects politics.

\section{REFERENCES}

[1] C. Caruth, Unclaimed experience: Trauma, Narrative, and History, The Johns Hopkins University Press, Baltimore, 1996.

[2] G. Deleuze, Bergsonism, New York: Zone Books, New York, 1988.

[3] J.C. Alexander, R. Eyerman, B. Giesen, N. J. Smelser, P. Sztompka, Cultiral Trauma and Collective Identity. Berkeley: University of California Press, 2004.

[4] A. G. Neal, National Trauma and Collective Memory: Major Events in the American Century, Armonk: M.E. Sharpe, 1998.

[5] A. Resnais, (Director), Hiroshima mon amour, [Motion picture], France: Gallimard, 1960.

[6] K. J. Sheriff, Charles Peirce's Guess at the Riddle Bloomington and Indianapolis: Indiana University Press, 1994.

[7] R. Uth, (Director), Korean War, [Motion picture], United States: New Voyage Communication, 2001.

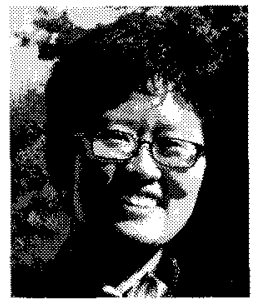

Ji-Young Yoo

She received the B.F.A., in Fine Art from Hong Ik University, Korea in 1991, and also received M.F.A., in Fine Art From City University of New York, New York in 2001, and M.A. in Media Studies from The New School, New York in 2005. Since then, she has been teaching at PuKyong National University, Dong-Eui Uniersity, Dongseo University and SungShin Women's University. She also participates various goup exhibitions. Her main research interests include video art and film. 